\title{
INTRAPRENEURSHIP APPROACH FOR TOURISM MANAGEMENT
}

\author{
Jyotirmoy Ghosh* and G. Anjaneya Swamy**
}

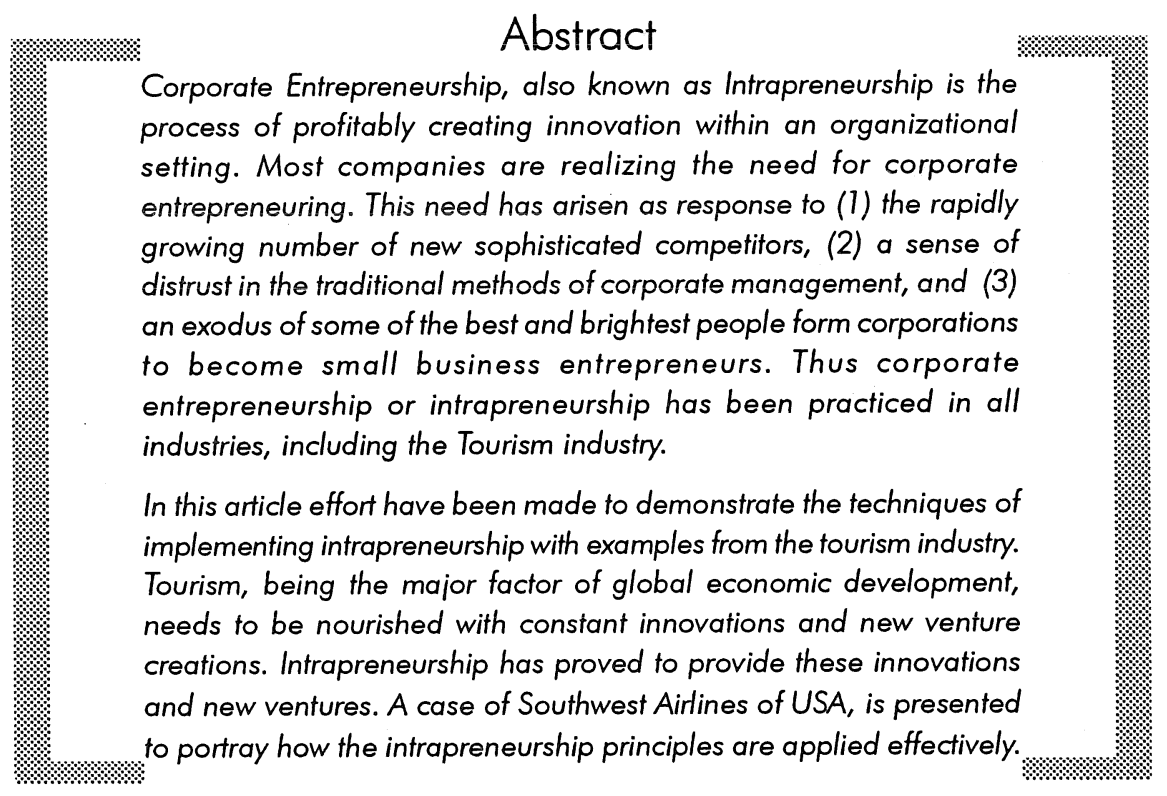

* Associate Professor, Department of Hotel Management, Christ College, Bangalore-560029 iyghosh@yahoo.com

** Professor \& Head, Department of Tourism Studies, Pondicherry University, Pondicherry. 
In recent years the subject of intrepreneurship has become quite popular, though very few people thoroughly understand the concept. Most researchers agree that the term refers to entrepreneurial activities that receive organizational sanction and resource commitments for the purpose of innovative results. The major thrust of intrapreneuring

is to develop the entrepreneurial spirit within organizational boundaries, thus allowing an atmosphere of innovation to prosper.

Intrepreneurs are not necessarily the inventors of new products or services but are the persons who can furn ideas or prototypes into profitable realities. They are the people behind a product or service. They are typically of average or slightly above- average intelligence- they are not genius.

Gifford Pinchot introduced the concept of Intrapreneurship in his best- selling book "Intrapreneuring". Pinchot honored the intrapreneurs with a mantle of heroism. According to Pinchot intrapreneurs are like corporate commandos and states "these courageous souls form underground teams and networks that routinely bootleg company resources or 'Steal' company time to work on their missions". In Pinchot's view, they make things happen, creating new commercial successes in spite of stodgy corporate policies and a glacial pace of bureaucratic decision making.

Two important points to emphasize are, first, that entrepreneurs are viewed, as disruptive mavericks prone to shatter the status quo and replace "What" by "What might be," and second, that very few entrepreneurs are motivated by money as much as by the pursuit of a vision to provide something of value. Wealth may come to those who succeed, but the pursuit of wealth is not itself a primary goal; money is simply one way to measure progress. With this in mind, Pinchot describes the corporate entrepreneur as someone who violates policy, ignores the chain of command, defies established procedures, and perhaps, comes up with a great new product for the company.

Success may garner bonuses for their champions; but failures can end in shattered careers. This perspective assumes that "Courageous souls" are at odds with their organizations, so much so that there is no tolerance for failure and only reluctant rewards for success.

The challenges of corporate management is to create a supportive environment that attracts, motivates and retains intrapreneurs - to instill a culture of innovation where renegades are empowered to pursue dreams and to fail without retribution. 
If organizations provide these support systems and also provide the entrepreneur with a safe salary, there should be no reason to start independent ventures; innovative employees would have the best of both worlds - income security and opportunity without risk.

The obstacles to corporate entrepreneuring usually reflect the ineffectiveness of traditional management techniques as applied to new-venture development. Although it is unintentional, the adverse impact of a particular traditional management technique can be so destructive that the individuals within an enterprise will tend to avoid corporate entrepreneurial behavior. After recognizing the obstacles, managers need to adapt to the principles of successful innovative companies. James Brain Quinn, an expert in the innovation field, found the following factors in large corporation that are successful innovative field, found the following factors in large corporations that are successful innovators:

Atmosphere and Vision: Innovative companies have a clear-cut vision of and the recognized support for an innovative atmosphere.

Orientation to the Market: Innovative companies tie their visions to the realities of the market place.

Small, flat organizations: Most innovative companies keep the total organization flat and project team's small.

Multiple approaches: Innovative managers encourages several projects to proceed in parallel development.

Interactive Learning: Within an innovative environment, learning and investigation of ideas cut across traditional functional lines in the organization.

Skunk Works: Every highly innovative enterprise uses groups that function outside traditional lines of authority. This eliminates bureaucracy, permits rapid turnaround, and instills a high level of group identity and loyalty.

The greatest Toursim Intrapreneurs of our times are Richard Branson of Virgin Airlines, Naresh Goyal of Jet Airways, Captain Gopinath of Air Deccan, and Lalith Suri of Bharat Hotels, to name a few from the long list. The stunning innovations of Richard Branson for marketing Virgin Airlines, have become lessons for all budding tourism executives. Captain Gopinath's sheer inclination to "dream the impossible "have spearheaded the phenomenal growth of Air Deccan. Lalith Suri's urge and capacity to infuse life into sick and losing hotel projects, helped him built the Bharat Hotels empire in India. Naresh Goyal's obsession for quality 
product and services, helped him acquire the ownership of Sahara Airlines which was riddled with bureaucracy and non profitability.

A study of all the above mentioned tourism intrapreneurial ventures revealed certain common corporate strategies they followed. All their corporate intrapreneurial strategies possessed four critical steps as

1) developing the vision.

2) encouraging innovation.

3) Structuring for an intrapreneurial climate and

4) developing venture teams.

\section{Developing the Vision}

It was noticed in all the companies, the planning stage had intrapreneurial strategics for their enterprises to share the vision of innovation that the corporate leaders wish to achieve. Since it was suggested that corporate entrepreneuring results from the creative talents of people within the organization, employees needed to know about and understand this vision. Shared vision was a critical element for a strategy that seeks high achievement. This shared vision required identification of specific objectives for corporate entrepreneuring strategies and of the programs needed to achieve those objectives. Captain Gopinath's original vision of providing the "Common man" of India the luxury of flying was the integral part of the intrapreneurial strategy. This vision gave birth to the logo of Air Deccan, of the "Common man" cartoon figure of R.K Laxman. Captain Gopinath was successful in sharing this vision with all his executives, cabin crew and other employees.

\section{Encouraging Innovation}

Innovation was proved to be the specific tool of the entrepreneurs. The corporations understood it and developed innovation as the key element in their strategy.

Innovation is described as chaotic and unplanned by some authors, while other researchers insist it is a systematic discipline. Both of these positions can be true depending on the nature of the innovation. The study on the four Tourism corporations revealed the innovations practiced were of two types: radical and incremental. 
Radical Innovation was the launching of inaugural breakthroughs such as apex fares, low cost airlines, smart basic hotels and selling low priced food and beverage during flights.

Incremental Innovation referred to the systematic evolution of a product or service into newer or larger markets. Examples include: Air Deccan venturing to all the major and minor routes in India; Bharat hotels venturing to almost thirty properties all over India and so forth.

Thus the study proved the radical innovations take experimentation and determined vision, which are not necessarily managed but must be recognized and nurtured. Many times the incremental innovation have taken over after a radical innovation introduced a breakthrough.

\section{Structuring for an Intrapreneurial Climate}

While re-establishing the drive to innovate in the tourism corporations, it was found, the final and possibly most critical step was to invest heavily in entrepreneurial activities that allowed new ideas to flourish in an innovative environment. This concept, when coupled with the other elements of an innovation strategy, enhanced the potential for employees to become venture developers. To develop employees as a source of innovation for corporations, companies provided more nurturing and information-sharing activities. In addition to establishing entrepreneurial ways and nurturing intrapreneurs, the companies developed a climate that helped innovative-minded people reach their full potential.

The study thus proved, for organizations to promote innovation among their employees, they must give careful attention to the moulding of an individual's attitude, values, and behavioral orientations with the organizational factors of structure and reward. Ultimately, the key objective is to enhance a firm's innovative abilities by developing an organizational environment supportive of individuals. In this context it is worth mentioning the research works of Vijay Sathe. Vijay Sathe, has suggested a number areas on which corporations must focus if they are going to facilitate intrapreneurial behavior. The first is to encourage not mandate- intrapreneurial activity. Managers should use financial rewards and strong company recognition rather than rules or strict procedures to encourage corporate entrepreneurship. This is actually a strong internal control and direction method than traditional parameters.

Another area expressed by Sathe, is the proper control of human resource policies. Managers need to remain in positions for a period long enough to allow them to learn an industry and a particular division. Rather than move managers around 
in positions, as is the case in many companies. Sathe suggests, selected rotation", in which mangers are exposed to different but related territories. This helps managers gain sufficient knowledge for new venture development.

A third factor is for management to sustain a commitment to intrapreneurial projects long enough for momentum to occur. Failures will inevitably occur, and learning must be the key aftermath of those failures. Thus sustained commitment is an important element in managing corporate entrepreneurship.

A final element Sathe mentioned is to bet on people, not on analysis. Although analysis is always important to judge a projects progression, it should be done in a supportive rather than an imposed style. The supportive challenge can help intrapreneurs realize errors, test their convictions, and accomplish a self-analysis.

\section{Developing Venture Teams}

All the four tourism corporations made good use of venture teams. Venture teams and the potential they hold for producing innovative results are recognized as a productivity breakthrough for the new millennium. Companies that have committed to a venture team approach often label the change they have undergone a "transformation" or a "revolution". This new breed of work team is a new strategy for many firms. Richard Branson always encouraged venture teams to aggressively market Virgin Airlines with innovative measures that created sensation all over the world.

Judith B. Kamm and Aaron J. Nurik in their book 'Entrepreneurship Theory and Practice" expressed "A venture team is composed of two or more people who formally create and share the ownership of a new organization". The unit is semiautonomous in the sense it has a budget plus a leader who has the freedom to make decisions within broad guidelines. Sometimes the leader is called a 'product champion' or an 'intrapreneur'.

At a macro level specific intrapreneurship strategies vary from firm to firm. However, they have similar patterns, seeking a proactive changing of the status and a new, flexible approach to operations management.

To illustrate most of the intrapreneurial measures discussed, the case of Southwest Airlines can be a good example in the tourism industry.

When Southwest Airlines first taxied onto the runway of Dallas's Love Field in 1971, industry gurus predicated it would be a short trip to bankruptcy for the 
Texas-based airline. But the first short-haul, low-fare, high frequency, point-topoint carrier took a unique idea and made it fly. Today, Southwest Airlines is the most profitable commercial airline in the world.

But it took more than a wing and a prayer for Southwest to soar to such lofty altitudes. It took a maverick spirit. From the beginning Southwest has flown against convention. Southwest's fleet of 737s the newest and safest in the industrystill makes only short hauls to 45 cities. The average flight distance is 394 miles. The airline does not offer baggage transfers or give seat assignments, and the only food it serves passengers is a bag of peanuts. But what Southwest may lack in amenities, it seems to more than make up for in what could be called positively outrageous service. "FUN" is the company's mandate!

Leading the way is founder and CEO Herb Kelleher. "Herb Kelleher is definitely the zaniest CEO in the world," Libby Sartain, vice president of Southwest Airlines People Department, admits. "Where else would you find a CEO who dresses up as Elvis Presley, who's on a first name basis with 20,000 employees, and who has a heart as big as the state of Texas? His style has fostered an atmosphere where people feel comfortable being themselves where they can have a good time when they work."

Legendary for his love of laughter, Kelleher calls his unique leadership style management by fooling around. "An important part of leadership, I think, is enjoying what your doing and letting it show to the people that you work with," Kelleher reveals. "And I would much rather have a company that is bound by love, rather than bound by fear." Kelleher's philosophy has been enthusiastically embraced by a work force that is 85 percent unionized. "Southwest's culture is designed to promote high spirit and avoid complacency. We have little hierarchy here. Our employees are encouraged to be creative and innovative, to break rules when they need to in order to provide good service to our customers," Sartain explains. "If you create the type of environment that a person really feels valued and They feel they make a difference, then they're going to be motivated that's the type of environment we create here for our employees," Rita Bailey, Sounthwest's director of training, adds.

Beginning with its new employee orientation, the airline nurtures intrapreneurship by grooming a work force of leaders. "You can do whatever it takes to keep this airline on top," an orientation instructor tells his class of newly hired staffers. At Southwest Airline's University for people, future managers and supervisors attend a course titled "Leading with integrity" Through a series of role-playing exercises; employees learn that trust, cooperation, mutual respect, and good communication are the components of success. "An organization that has an esprit, that does 
things cooperatively and voluntarily rather than through coercion, is the most competitive organization you can have," Kelleher asserts. These guiding principles have earned Southwest Airlines the distinction of being named one of the ten best companies to work for in America.

Employees are valued and recognized in many ways for their achievements. Perhaps the most prestigious is Southwest's "Heroes of the Heart" award. Each year, one outstanding department has its name tattooed on a Southwest Jet. Southwest was the first airline to offer stock options to its employees. Today, employees own approximately 10 percent of the company.

In the lobby of Southwest Airline's corporate headquarters is a prominent tribute to the men and women of Southwest. It reads: "The people of Southwest Airlines are the creators of what we have become - and what we will be our people transformed an idea into a legend. That legend will continue to grow only so long as it is nourished by our people's indomitable spirit, boundless energy, immense goodwill, and burning desire to excel. Our thanks and our love to the people of Southwest Airlines for creating a marvelous family and wondrous Airline."

\section{References}

1. Robert B.Reich "The Team as Hero," Harvard Business Review (May/June 1987)

2. Philip D. Olson, "Choices for Innovation-Minded Corporations," Journal of Business strategy (January/February 1990)

3. Michael H.Morris and Donald F.Kuratko, "Corporate Entrepreneurship" Mason, Ohio : SouthWestern, 2002)

4. David H. Holt, 'Entrepreneurship-New Venture Creation.' (Prentice-Hall Inc 1992. NewDelhi)

5. Gifford-Pinchot 111, 'Intrapreneuring' (New York: Harper and Row 1985)

6. Vijay Sathe, 'From Surface to Deep Corporate Entrepreneurship," Human Resources Management(Winter1988): 389-411 